ACTA AGROBOTANICA

Vol. 59 z. 22006

s. 715

\title{
Localization of ginsenosides in Panax quinquefolium root tissues
}

\author{
AGNIESZKA LUDWICZUK ${ }^{1}$, \\ ELŻBIETA WERYSZKO-CHMIELEWSKA ${ }^{2}$, \\ TADEUSZ WOLSKI ${ }^{1,3}$
}

\author{
${ }^{1}$ Department of Pharmacognosy with Medicinal Plant Laboratory, Skubiszewski Medical \\ University, 1 Chodźki Street, 20093 Lublin, Poland \\ ${ }^{2}$ Department of Botany, University of Agriculture, 15 Akademicka Street, 20950 Lublin, Poland \\ ${ }^{3}$ Department of Vegetable and Medicinal Plant, University of Agriculture, \\ Leszczyńskiego 58, 20068 Lublin, Poland
}

(Received: 12.05.2006)

\section{S u m m a r y}

We carried out histochemical studies to find the localization of ginsenosides in roots of Panax quinquefolium cultivated in Poland. We performed an anatomical study on the structure and localization of secretory canals on the cross section of 4-year-old American ginseng roots. We observed the occurrence of large secretory canals, mainly in the middle part of the secondary cortex and less in the phloem layer. In our studies, moreover, we demonstrated the production of secretory canals within the periderm layer. After the anatomical study, the 4-year-old ginseng root was divided into periderm, cortex and xylem, and the ginsenosides were extracted from each part of the root. The TLC separation of ginsenosides was performed on silica gel Si60 glass plates with chloroform-methanol-ethyl acetate-water-hexane, $20+22+60+8+4$ $(v / v)$ as mobile phase. Quantitative analysis of ginsenosides was performed by using the TLC-densitometric method. Concerning the distribution of ginsenosides in the different anatomical parts of the root of Panax quinquefolium, they were contained in the periderm layer at the highest level.

Key words: Panax quinquefolium, ginsenosides, roots, anatomical study, thin layer chromatogra phy (TLC), densitometry

\section{INTRODUCTION}

Ginseng is one of the most popular herbs in the world. Panax ginseng C.A. Mayer (Asian ginseng) and Panax quinquefolium L. (American ginseng) represent primary sources of the herb commonly referred to as ginseng. Ginseng has been used 
for centuries as general tonic and adaptogen to help the body to resist the adverse influences of a wide range of physical, chemical and biological factors (G old st a in, 1975; Lut o m ski and Kędzia, 2000; Necerin o et al., 2000; Radad et al. 2004). In trade there are found whole roots, the roots in cut and powdered form, tablets, capsules, tinctures, syrups or extracts. Ginseng is also present in cool drinks, as an additive in sweets, and also in cosmetics, e.g., creams and shampoos (B e r beć and Dziedzic, 1996; S ticher, 1998).

Growing demand for ginseng products and depletion of natural resources have prompted experiments on ginseng cultivation, initially in Asian countries, now also in Poland (B erbeć and Dziedzic, 1996; Kołodziej, 2003). Nowadays, almost all raw material is derived from cultivation.

Panax quinquefolium is a slow growing perennial herb of the Araliaceae family. The plants are from 30 to $80 \mathrm{~cm}$ high. A first-year seedling has three leaflets. The leaf and leaf petiole is 5 to $10 \mathrm{~cm}$ high. The root is generally less than $1 \mathrm{~g}$ after the first growing season. With age the plant increases in size. Second-year plants $(15-20 \mathrm{~cm})$ generally have one stem and two leaves, each with 3 to 5 leaflets. In subsequent years, the plants have three, four or five leaves, and roots are growing up to 25 grams and forming branches with long hairs. Flowering occurs in late spring during the third (sometimes in second) and later years of vegetation. The flowers are greenish-white and grouped in a spherical cluster. In August and September, bright red fruits develop from the flowers (S z weykowska and Szweykowski, 1993; B erbeć and Dziedzic, 1996; Schluter and Punja, 2000; PDR, 2000; Kołodziej, 2002; Kołodziej, 2003).

The principal constituents of American ginseng (Panax quinquefolium L.) and also other Panax sp. are ginsenosides. Ginsenosides have been classified in three groups: 20(S)-protopanaxadiols ( $\mathrm{Rb}_{1}$ group), 20 (S)-protopanaxatriols ( $\mathrm{Rg}_{1}$ group) and oleanolic acids. More than 30 different ginsenosides are known. Seven of these, $\mathrm{Rg}_{1}$, $\mathrm{Re}, \mathrm{Rf}, \mathrm{Rb}{ }_{1}, \mathrm{Rc}, \mathrm{Rb}_{2}$ and $\mathrm{Rd}$ are the major ginsenosides accounting for over $90 \%$ of the saponin content (Sticher, 1998; A t te le et al. 1999).

Ginsenosides are the components that give ginseng its valuable properties. Some of the ginsenosides have opposing activities, e.g. ginsenoside $\mathrm{Rg}_{1}$ raises the blood pressure and is a central stimulant, while ginsenoside $\mathrm{Rb}_{1}$ lowers the blood pressure and is a central depressant. American ginseng contains primarily ginsenoside $\mathrm{Rb}_{1}$, which is also antihemolytic, antipyretic, antipsychotic, and decreases islet insulin concentration (Kang et al. 1995; Sticher, 1998; Attele et al. 1999; $\mathrm{R}$ ad ad et al. 2004).

In the present investigations, we carried out histochemical studies to find the localization of ginsenosides in roots of Panax quinquefolium cultivated in Poland.

\section{MATERIAL AND METHODS}

\section{Plant material}

Fourth year roots of American ginseng (Panax quinquefolium L.) cultivated in climatic conditions of Lubelszczyzna (Poland) and collected in September 2003, were used for the investigations. 


\section{Anatomical study}

Fresh root transverse cuttings were stained with methylene blue to distinguish the secretory tissue and treated with Sudan III. Durable microscopical slides were made from samples of ginseng roots fixed in $2.5 \%$ glutaraldehyde in $0.1 \mathrm{M}$ cacodylic buffer ( $\mathrm{pH}$ 7.4). They were dehydrated and then placed in propylene oxide and embedded in SPURR resin. Preparations were cut using the ultramicrotom Reichert Ultracut S. Semi-thin slices were colored with $1 \%$ methylene blue with $1 \%$ azure II.

\section{Extraction and determination}

Ginseng root was divided into periderm, cortex and xylem. $1 \mathrm{~g}$ of each tissue was extracted with $50 \%$ aq. methanol in a shaker. The extracts were combined, filtered, and evaporated to dryness by rotary vacuum evaporation at $60^{\circ} \mathrm{C}$. The residue was dissolved in $50 \%$ aq. methanol $(25 \mathrm{ml}) .5 \mathrm{ml}$ of this solution was applied to $\mathrm{C}_{18} \mathrm{SPE}$ microcolumn (prewashed with $10 \mathrm{ml}$ methanol and $10 \mathrm{ml}$ water). After washing with $10 \mathrm{ml}$ water and $10 \mathrm{ml} \mathrm{30 \%}$ aq. methanol, the ginsenosides were eluted with $10 \mathrm{ml}$ of methanol.

The thin layer chromatographic separation of ginsenosides was performed on silica gel Si60G glass plates (Merck, Germany), in a horizontal chamber (Chromdes, Poland) using mobile phase: chloroform methanol ethyl acetate water hexane, $20+22+60+8+4(v / v)$. Samples were spotted on the plates with a TLC III applicator (Camag, Switzerland). After separation the plates were dried and sprayed with Godin's reagent (A: $5 \%$ solution of $\mathrm{H}_{2} \mathrm{SO}_{4}$ in ethanol; B: $1 \%$ solution of vanillin in ethanol) and heated at $105^{\circ} \mathrm{C}$ for $10 \mathrm{~min}$. Quantitative densitometric evaluation was performed at wavelength of $540 \mathrm{~nm}$ with the Camag densitometer (Switzerland) (L u d w i c z u k et al. 2005).

\section{RESULTS AND DISCUSSION}

We performed an anatomical study on the structure and localization of secretory canals on the cross section of 4-year-old American ginseng roots. The largest canals were dispersed mostly in the middle and outer parts of the secondary cortex (Figs. 1-3). We observed some canals in the periderm tissue (Figs. 1, 4). The canals with the smallest diameter were situated in the phloem, not far away from cambium (Fig. 2).

Histochemical analysis of fresh root tissues stained with methylene blue confirmed a big concentration of canals in the middle part of the cortex (Figs. 5, 6). The cell contents of the secretory epithelium surrounding canals and periderm parenchyma were dark blue stained and it points at the intensive metabolic activity of these tissues. Treatment with Sudan III revealed the presence of lipid compounds not only in secretory cells around the canals, but also in the parenchyma cells situated between neighboring canals (Fig. 7). Within the xylem, we did not find structures resembling canals. We observed not numerous concentrations of radially arranged vessels and single cells or groups of cells with dark stained protoplasts, which could fulfill secretory functions.

In the semi thin slides, about $0.5 \mathrm{~mm}$ thick, we noticed homogenous or grained secretion within the canals. Secretory epithelium cells formed 1-2 layers surrounding the canals (Figs. 3, 4). 

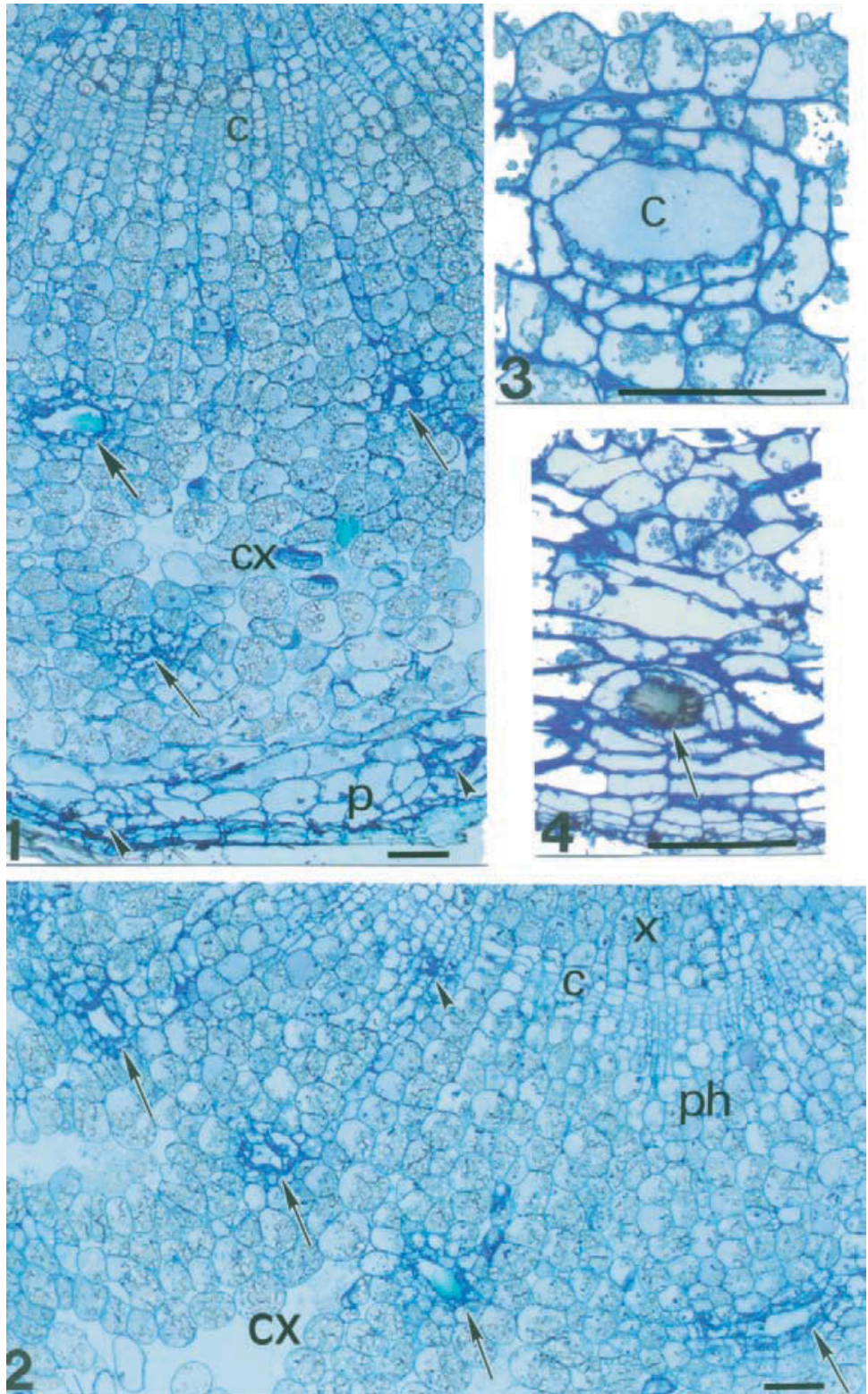

Fig. 1. Fragment of the cross section of 4 years old American ginseng root with visible secretory canals (arrows and arrowheads), bar $=100 \mu \mathrm{m}$.

c cambium; $c x$ cortex; $p$ periderm

Fig. 2. Middle part of the root cross section with canals in the cortex perenchyma (arrows) and in the phloem (arrowhead), bar $=100 \mu \mathrm{m}$.

c cambium; cx cortex; ph phloem; $x$ xylem

Fig. 3. Cross section of the secretory canal (C) in the middle part of the cortex, bar $=100 \mu \mathrm{m}$.

Fig. 4. Peripheral part of the root with secretory canal (arrow) in the periderm, bar $=100 \mu \mathrm{m}$. 

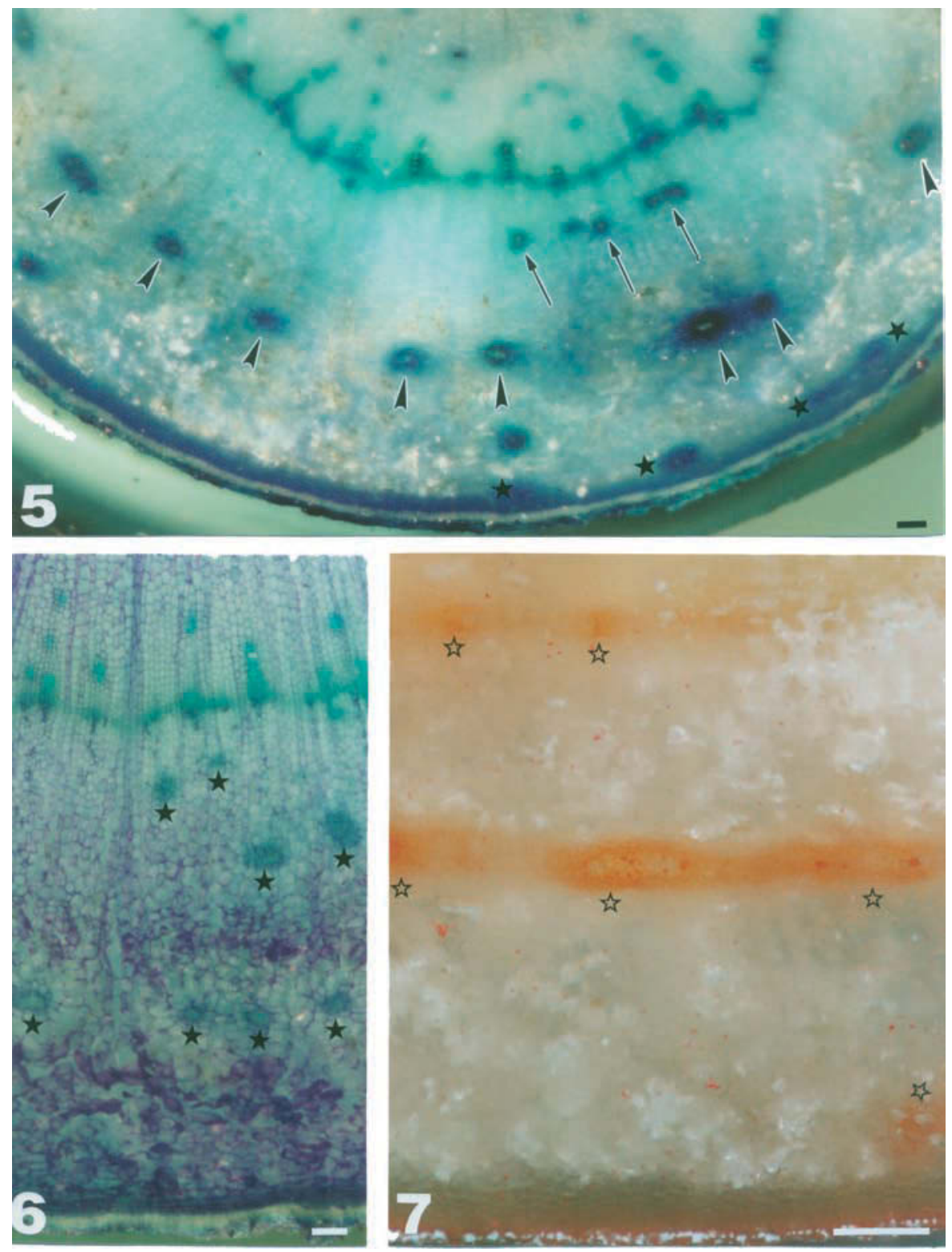

Fig. 5. Fragment of the root cross section after methylene blue staining. Visible canal in the phloem (arrows), middle cortex (arrowheads), periderm (stars), bar $=100 \mu \mathrm{m}$.

Fig. 6. Part of the root cross section after methylene blue staining. Canals are pointed with stars, bar $=100 \mu \mathrm{m}$.

Fig. 7. Fragment of the root cross section after Sudan III treatment. Canals localization was marked with stars, bar $=100 \mu \mathrm{m}$. 


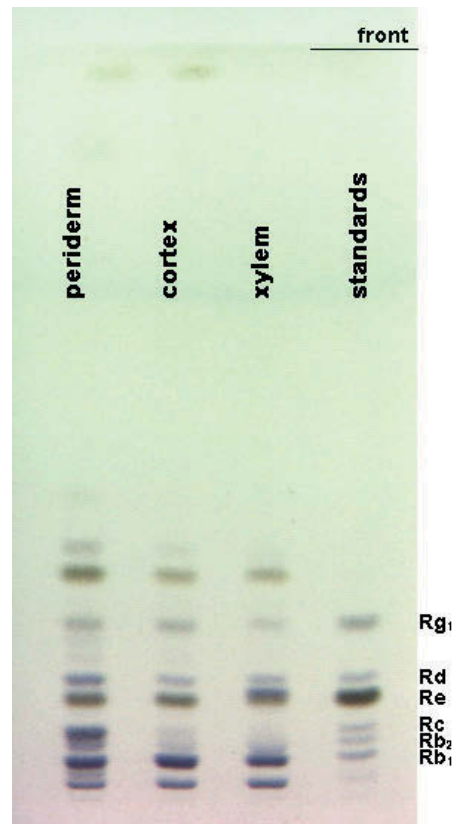

Fig. 8. Videoscan of ginsenosides occurring in Panax quinquefolium root tissues.

The occurrence of large secretory canals in the roots of American ginseg, mainly in the middle part of the secondary cortex and less frequently in the phloem layer, is approximate to the localization of these canals in Asian ginseng roots, what is described in Kubo et al. (1980).

In our studies, moreover, we demonstrated the production of secretory canals within the periderm layer and intensive staining of cell contents of periderm parenchyma after methylene blue treatment.

As results from the previous paper ( $\mathrm{K} \mathrm{u} \mathrm{bo}$ et al. 1980), ginsenosides were considered to be localized in the secretion canals and surrounding zones of the cortex of ginseng root. We performed quantitative analysis of main ginsenosides in the outer and inner parts of the Panax quinquefolium root. These investigations were concerned with the distribution of ginsenosides in periderm, cortex and xylem of the root. For the determination, the TLC-densitometric method was used. The method is quick, sensitive and linear in the concentration range tested (Table 1). The limit of detection for the ginsenosides is $76-89 \mathrm{ng} / \mathrm{spot}$.

Table 1

Linear calibration curves, concentration range, LOD, LOQ and recoveries.

\begin{tabular}{|c|l|c|c|c|c|c|}
\hline Saponins & Calibration curve & $\mathrm{r}^{2}$ & $\begin{array}{c}\text { Concentration } \\
\text { range }[\mu \mathrm{\mu g} / \text { spot] }\end{array}$ & $\begin{array}{c}\text { LOD } \\
{[\mathrm{ng} / \mathrm{spot}]}\end{array}$ & $\begin{array}{c}\text { LOQ } \\
{[\mathrm{ng} / \text { spot] }]}\end{array}$ & $\begin{array}{c}\text { Recovery } \\
{[\%]}\end{array}$ \\
\hline $\mathrm{Rb}_{1}$ & $y=4758.2 x+3606.8$ & 0.9949 & $5.0-15.0$ & 89.0 & 295.0 & 97.6 \\
$\mathrm{Rc}$ & $y=8703.2 x+570.03$ & 0.9915 & $1.0-10.0$ & 84.0 & 282.0 & 96.8 \\
$\mathrm{Re}$ & $y=2057.2 x+6411.2$ & 0.9956 & $1.0-10.0$ & 81.0 & 270.0 & 88.8 \\
$\mathrm{Rd}$ & $y=2095.1 x+5279.2$ & 0.9939 & $0.1-5.0$ & 78.0 & 260.0 & 101.2 \\
$\mathrm{Rg}_{1}$ & $y=19644 x+464.69$ & 0.9982 & $0.1-5.0$ & 76.0 & 253.0 & 89.7 \\
\hline
\end{tabular}


Table 2

Percentage content of the main ginsenosides occurring in Panax quinquefolium tissues.

\begin{tabular}{|c|c|c|c|c|c|c}
\hline \multirow{2}{*}{ Tissue } & \multicolumn{5}{|c}{ Ginsenosides content [\%] } \\
\cline { 2 - 7 } & $\mathrm{Rb}_{1}$ & $\mathrm{Rc}$ & $\mathrm{Re}$ & $\mathrm{Rd}$ & $\mathrm{Rg}_{1}$ & $\mathrm{Total}^{*}$ \\
\hline Periderm & $0.546 \pm 0.011$ & $0.294 \pm 0.028$ & $0.468 \pm 0.020$ & $0.256 \pm 0.009$ & $0.019 \pm 0.003$ & 1.583 \\
\hline Cortex & $0.415 \pm 0.021$ & - & $0.290 \pm 0.010$ & $0.042 \pm 0.001$ & $0.028 \pm 0.003$ & 0.775 \\
\hline Xylem & $0.298 \pm 0.027$ & - & $0.275 \pm 0.009$ & $0.060 \pm 0.004$ & $0.012 \pm 0.002$ & 0.645 \\
\hline Total & 1.259 & 0.294 & 1.033 & 0.358 & 0.059 & 3.003 \\
\hline
\end{tabular}
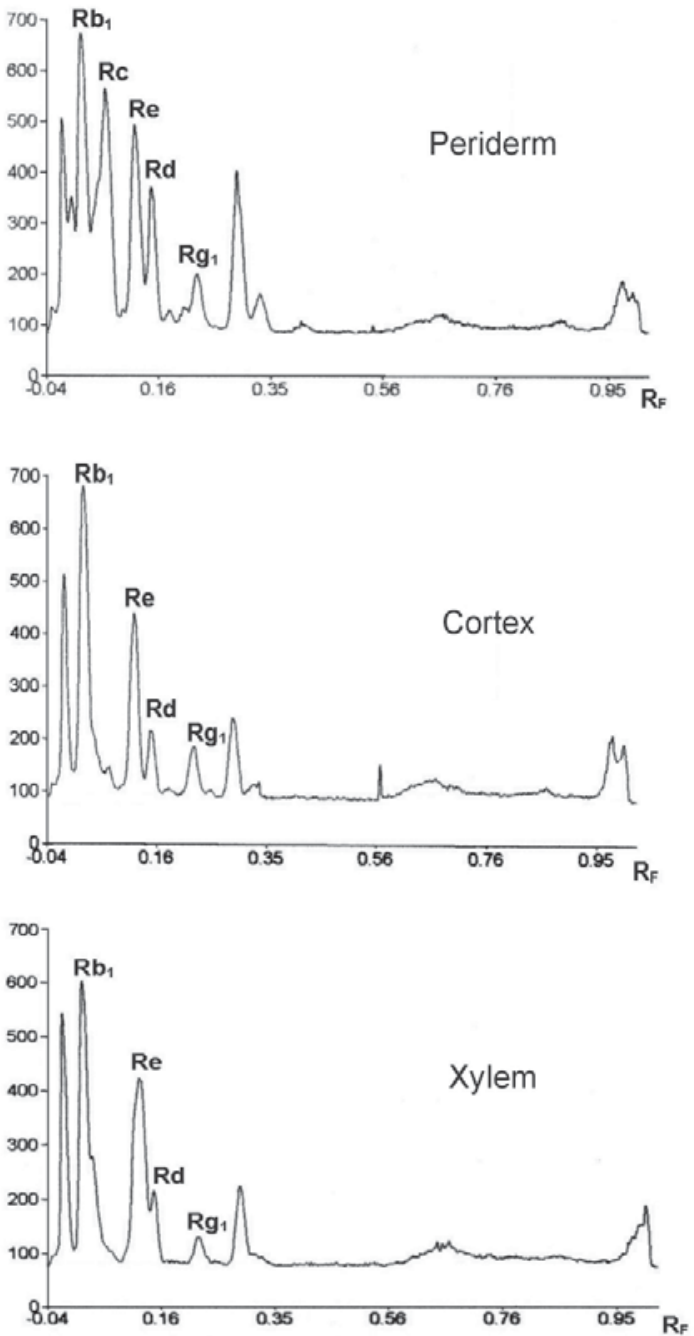

Fig. 9. Densitograms of ginsenosides occurring in ginseng root tissues. 
The conditions used for thin layer chromatography:

stationary phase; silica gel Si60G

$>$ mobile phase; $\mathrm{CHCl}_{3}$ MeOH EtOAc $\mathrm{H}_{2} \mathrm{O}$ hexane, 20+22+60+8+4 $(v / v)$ resulted in good separation of the ginsenosides. Results from TLC separation of ginsenosides are illustrated in Figure 8 and the densitograms of ginsenosides occurring in tissues of the ginseng root in Figure 9.

Numerical data concerning the content of five major ginsenosides in American ginseng root tissues are presented in Table 2.

In the root of Panax quinquefolium, ginsenosides have been found in all investigated tissues, but the periderm is characterized by the highest concentration of saponins $(1.583 \%)$. In the cortex, the content of ginsenosides amounted to $0.775 \%$, and in the xylem $0.645 \%$. Four from five investigated compounds were localized in all investigated tissues, but ginsenoside Rc was found only in the periderm.

The anatomical study demonstrates that the periderm layer was characterized by great metabolic activity. These data were confirmed by our quantitative analysis, relating to the maximum concentration of ginsenosides in the peripheral tissues of American ginseng root. The investigations conducted by Samukawa et al. (1995) also showed that ginsenosides were distributed much richer in the periderm than in other parts of ginseng root.

Commercial white ginseng is made by removing the outer peel of the root (periderm) (K u b o et al. 1980; Ta n i et al. 1981). Such processing, in case of Panax quinquefolium, should result in a loss of $53 \%$ of ginsenosides.

\section{CONCLUSIONS}

1. Anatomical study of 4-year-old ginseng root indicated presence of secretion in epitel cells and in secretion canals localized in middle and outer part of secondary bark.

2. The periderm is characterized by the highest concentration of ginsenosides $(1.583 \%)$. The total ginsenosides content in Panax quinquefolium root amounted $3.003 \%$.

3. Removal of the peel, in case of Panax quinquefolium, should result loss of $53 \%$ of ginsenosides.

\section{REFERENCES}

Attele A. S., Wu J. A., Yuan C. S., 1999. Ginseng pharmacology: multiple constituents and miltiple actions. Biochem. Pharmacol. 58 (11): 16851693.

Berbeć S., Dziedzic M., 1996. Uprawa żeń szenia amerykańskiego. Wyd. Akad. Roln. w Lublinie, Lublin.

Goldstein B., 1975. Ginseng: its history, dispersion, and folk tradition. American J. Chin. Med. 3 (3): 223234.

Kang S. Y., Schini Kerth V. B., Kim N. D., 1995. Ginsenosides of the protopanaxatriol group cause endothelium dependent relaxation in the rat aorta. Life Science, 56: 15771586. 
Kołodziej B., 2002. The effect of soil disinfections with selected chemicals on the growth and development of American ginseng (Panax quinquefolium L.). Folia Hortic. 14 (2): 177182.

Kołod zi ej B., 2003. Studia nad wzrostem, rozwojem oraz uprawą żeń szenia amerykańskiego (Panax quinquefolium L.). Rozprawa habilitacyjna. Wyd. Akad. Roln. w Lublinie, Lublin, pp. 103.

Kubo M., Tani T., Katsuki T., Ishizaki K., Arichi S., 1980. Histochemistry. I. Ginseno sides in ginseng (Panax ginseng C.A. Meyer). J. Nat. Prod. 43 (2): 278284.

Ludwiczuk A., Nyiredy Sz., Wolski T., 2005. Separation of ginsenosides fraction obta ined from roots of Panax quinquefolium L. cultivated in Poland. J. Planar Chromatogr. 18: 104107.

Lu to m sk i J., Kę d zi a B., 2000. Ocena aktywności biologicznej roślin o działaniu adaptogen nym. Postępy Fitoterapii, 2: 3135.

Necerino E., A mato M., Izzo A. A., 2000. The aphrodisiac and adaptogenic properties of ginseng. Fitoterapia, 71 (1 Suppl): 5155.

PDR $^{\circledR}$ for Herbal Medicines ${ }^{\mathrm{TM}}$, 2000. Medicinal Economics Company, Montvale, New Jersey: 346351.

R adad K., Gille G., R a u s ch W. D., 2004. Use of ginseng in medicine: perspectives on CNS disorders. IJPT, 3: 3040.

Samukawa K., Yamashita H., Matsuda H., Kubo M., 1995. Simultaneous analysis of ginsenosides of various Ginseng radix by HPLC. Yakugaku Zasshi, 115 (3): 241249.

Schluter C., Punja Z. K., 2000. Floral biology and seed production in cultivated North American ginseng (Panax quinquefolius). J. Amer. Soc. Hort. Sci. 125 (5): 567575.

Sticher O. (1998), Getting to the root of ginseng. CHEMTECH, 28 (4): 2632.

Szweykowska A., S zwe yk ow ski J. (Ed.), 1993. Słownik botaniczny. Wiedza Powszech na. Warszawa.

Tani T., Kubo M., Katsuki T., Higashino M., Hay ashi T., Arichi S., 1981. Histoche mistry. II. Ginsenosides in ginseng (Panax ginseng, root). J. Nat. Prod. 44 (4): 401407.

\section{Rozmieszczenie ginsenozydów w tkankach korzeni Panax quinquefolium}

\section{Streszczenie}

W celu określenia lokalizacji ginsenozydów w korzeniach żeń-szenia pięciolistnego (Panax quinquefolium L.) uprawianego w Polsce, przeprowadzono badania histochemiczne. Badania anatomiczne dotyczące budowy i rozmieszczenia kanałów wydzielniczych wykonano na przekrojach poprzecznych 4-letnich korzeni żeń-szenia. Z obserwacji mikroskopowych wynika, że największe kanały wydzielnicze są zlokalizowane w środkowej i zewnętrznej części kory wtórnej. Kanały o mniejszej średnicy położone były w obrębie floemu. Wykazano ponadto występowanie kanałów wydzielniczych w tkankach perydermy. Do badań analitycznych korzenie żeńszenia podzielono na trzy części (perydermę, korę i floem), a następnie wyekstrahowano z nich frakcje ginsenozydów. Analizę ilościową ginsenozydów prowadzono metodą TLC na płytkach szklanych pokrytych żelem krzemionkowym Si60 przy użyciu fazy ruchomej: chloroform metanol octan etylu woda heksan, $20+22+60+8+4(v / v)$. Rozwinięte płytki poddawano analizie densytometrycznej. Analiza ilościowa ginsenozydów w różnych tkankach korzeni Panax quinquefolium wykazała największą zawartość tych związków w perydermie. 
